\title{
THE IMPACT OF JOB INSECURITY, ROLE AMBIGUITY, SELF MONITORING AND PERCEIVED FAIRNESS OF PREVIOUS CHANGE ON INDIVIDUAL READINESS FOR CHANGE
}

Asli GOKSOY

American University in Bulgaria

\begin{abstract}
Every organization faces some type of change in today's business world. Research shows that organizational change initiatives fail at an alarming rate. One rationale for not being able to manage change through to success is a failure to create readiness for change in the first place. Additionally, low readiness leads to active resistance. In order to have a successful, painless change process, organizations need their employees support the change, in other words, employees need to be "bought in" and committed. Employees will support change, if they are ready for it. In this frame work, it is important to understand the employee readiness concept and its antecedents in order to create the right change strategies. This study focuses on the impact of job insecurity, role ambiguity, self monitoring and perceived fairness of previous change on individual readiness for change. The survey of this study is conducted on 464 employees who experienced at least one organizational change in previous year in their organization. The obtained data from the questionnaires are analyzed through the SPSS. Analyses results revealed that job insecurity, role ambiguity, self monitoring and perceived fairness of previous change have impact on readiness for change. These meaningful results will provide some useful guidance to managers, change agents, practitioners and consultants.
\end{abstract}

Keywords: Job insecurity; Role ambiguity; Self monitoring; Perceived fairness of previous change; Readiness for Change

\section{INTRODUCTION}

In today's turbulent environment of organizations, change has become synonymous with standard business practices as long-term organizational ends have to be reformulated on an ongoing business. With this mind, if anything has remained constant in the history of organizations, it has been change. Consequently, the first decade of the new millennium has been forecasted to be a period of tremendous change in the workplace (Gordon et al., 2000). Managing organizational change is, in a very large part, about managing the "people" aspects of the process, because employees are the real source of and vehicle for change (Smith, 2005). Correspondingly, employees' readiness is one of the most important aspects of change because readiness is associated with a belief, attitudes and intentions regarding the extent to which changes are needed and the organization can change successfully. It is viewed as the precursor to the behaviors of either resistance to or support for a change effort undertaken by an organization (Rafferty and Simons, 2001). In this study, the impact of job insecurity, role ambiguity, self monitoring and perceived fairness of previous change on individual readiness for change are investigated. For organizations to assist employees in being motivated and prepared for change, it is essential that managers, leaders, and organization development professionals understand factors that may influence individual change readiness (Madsen et al., 2005). Additionally, readiness prevents resistance. Many organizational changes fail because managers and change agents diagnosis the situation poorly and cannot handle resistance properly. By accurately assessing individual readiness, leaders, managers, and change agents can overcome resistance by preparing employees to absorb and adapt the change. Therefore, this study is important and provides some useful information.

\section{LITERATURE REVIEW AND HYPOTHESES}

\section{Individual Readiness for Change}

Although the concept of readiness has been first introduced by Jacobson in 1957, the foundation for readiness as a unique construct has been embedded within several theoretical models of the process 
through which change unfolds. Readiness for organizational change refers to individuals' beliefs, attitudes and intentions regarding the extent to which changes are needed and the organization's capacity to successfully undertake those changes (Armenakis et al., 1993). Readiness for change begins with an individual's perception of the benefits of change (Prochaska et al., 1994) the risks of failing to change (Spector, 1989) or the demands of externally imposed changes (Pettigrew, 1987). Holt and colleagues (2007) defined change readiness as a "comprehensive attitude that is influenced simultaneously by the content (i.e., what is being changed), the process (i.e., how the change is being implemented), the context (i.e., circumstances under which the change is occurring), and the individuals (i.e., characteristics of those being asked to change) involved" (Holt et al., 2007).

Readiness may vary due to changing external or internal circumstances, the type of change being introduced, or the characteristics of potential adopters and change agents (Backer, 1995). There are many individual factors [e.g. age, education, gender (Noe et al., 1997), and self-efficacy (Eby et al., 2000)], and organizational factors [e.g. trust in leadership and peers, flexible policies and procedures (Rafferty and Simons, 2006)] that can affect the level of individual readiness.

Organizational psychologists agree that change readiness is an important element for successful organizational change (Sokol, 1997). If employees do not believe that change is needed, or if they feel the organization will not be able to change then change initiatives may fail (Cunningham et al., 2002). Individual readiness to change is also frequently studied within the context of resistance to change, because when readiness for change exists, the organization is primed to embrace change and resistance is reduced. If organizational members are not ready, the change may be rejected, and organizational members may engage in negative reactions such as sabotage, absenteeism and output restriction. In conclusion, one important factor influencing the successful implementation of systemwide change is initial readiness of those involved individually and collectively (Holt et al., 2009) and readiness for change is the cognitive precursor to resistance for change and thus, it has most often been invoked along with prescriptions such as education, communication, involvement and support for reducing resistance (Armenakis et al., 1993). That is, these prescriptions have been shown to effectively reduce resistance by first creating readiness to change (Kotter and Schlesinger, 1979).

\section{Job Insecurity}

Job insecurity is defined as the threat of job loss or job uncertainty (De Witte, 1999). Greenhalgh and Rosenblatt (1984) explains it as "perceived powerlessness to maintain desired continuity in a threatened job situation". Increasing global competition, the rise of outsourcing, cost-cutting pressures, and the implementation of lean production environments are but a few of the factors that have led to widespread corporate layoffs, workplace restructuring, and a heavier reliance on the contingent workforce. Due to these phenomena, specifically, employees of the new millennium must contend with the reality of mounting job insecurity and the ever-present potential for unemployment and redundancy (Probst and Strand, 2010).

Change represent something new, in other words change means moving from status quo to a new direction. This movement can cause fear, fear of unknown and unclearness, also sometimes danger. When change is introduced, people feel a loss of control (Evans, 2001), change initiative imply a loss of the security that goes with a specific job. Especially in the last decade, in order to cope with increased economic pressure, organizations in many industrialized countries have engaged in restructuring, mergers, acquisitions, and 'right-sizing' programmes (Hirsch and De Soucey, 2006) that are accompanied by a workforce reduction and a more flexible use of labour (e.g. part-time or temporary jobs). As a consequence, an increasing number of employees feel insecure about the future existence of their jobs (Burchell, 2002). On the top of this reality, organizational changes have produced evidence that employers no longer promise job security and long term employment, not even to its loyal employees (Witten, 1989). For example, when managers decide to restructure, organizational changes usually include workers losing their jobs (Petzall et al., 2000). In conclusion, if employees feel job insecurity, they will not feel ready for change as they will not be motivated, not welcome the idea of change with excitement and clearly define the change as a treat for themselves. Therefore;

H1: Job insecurity will have a negative impact on individual readiness for change. 


\section{Self Monitoring}

The self-monitoring, as a general personality construct has been addressed extensively by Synder (1987) and Lennox and Wolfe (1984), who have linked the tendency to alter one's behavior based on situational cues in the environment to such skills as sensitivity to social cues, appropriate emotional expression and self-control. High self monitors continually scan the social climate around them and adapt their behavior so that it is appropriate to the situation. Consequently, high self monitors are motivated to engage in those behaviors that will help them be accepted and/or gain status (Gangestad and Snyder, 2000).

Organizational changes are mostly defined as unfamiliar and uncertain times for employees. Members look to one another for clues regarding the meaning of events and circumstances facing the organization as a whole (Armenakis et al., 1993). High self monitors are willingness to adapt and modify self-presentation and behavior to fit a social situation (Snyder and Copeland, 1989). In contrast, low self-monitors find it difficult to distinguish their feelings and reactions and cannot adapt quickly to situations. Therefore, high self monitors will collect more clues in a shorter time frame, analyze them quickly and accept them the new situation faster. Additionally, faced with a social situation, high self-monitors ask: 'Who does this situation want me to be and how can I be that person (Snyder, 1979). Consequently, they will feel readier than low self monitoring employees. Therefore;

H2: High self monitoring will have a positive impact on individual readiness for change.

\section{Role Ambiguity}

According to role theory, role ambiguity refers to the lack of specificity and predictability for an employee's job or role functions and responsibility and the single or multiple roles that confront the role incumbent, which may not be clearly articulated in terms of expectations, priorities, behaviors or performance levels (Kahn et al., 1964). Peterson and his colleagues (1995) expand the definition of role ambiguity to include uncertainty about what actions to take to fulfill a role. Forte and his colleagues (2000) claim that role ambiguity may result from changes to the external environment and the subsequent reactions that impact organizational form or structure.

The lack of clarity resulting from ambiguity creates feelings of threat and resentment toward the change and fear of the unknown. Bedian and Armenakis (1981) have established a causal relationship between role ambiguity and increased tension, frustration, and anxiety. Role ambiguity may occur when the expectations applicable to the old organization have not been replaced by clear expectations set by the new organization. In addition to experiencing uncertainty over the nature of present and future job roles, employees may perceive change as a major source of threat to their roles in organization. Under these circumstances, employees will not hold positive views about the need for change and will not believe change is likely to have a positive implication for them. Therefore,

\section{H3: Role ambiguity will have a negative impact on individual readiness for change.}

\section{Perceived Fairness Of Previous Change}

In organizational justice theory, perceptions of fairness in organizations are explained by categorizing employees' views and feelings about their treatment and that of others within the organization (Greenberg, 1987). Fairness of change processes have included practices such as providing advanced notice of changes and showing respect for the affected individuals (Brockner et al., 1994), being open to and considerate of participants' concerns (Korsgaard et al., 1995) and providing the opportunity to express one's views that can affect ultimate outcomes (Folger, 1977). The way in which individuals are treated during a period of change has been found to affect their perceptions about the fairness of the process (Folger and Cropanzano, 1998). Prior experience has been found to be an important determinant of behavior (Bagozzi, 1981). Ericksson's study (2004) found that historical memory of past change efforts directly impacted employees' emotions during current organizational change plans. The past change programs had left sediment in the minds of the employees that manifested itself as general fatigue and lethargy. Specifically, it has been suggested that knowledge gained from past behavior will help to shape intention (Fishbein and Ajzen, 1975), in part, because experience makes knowledge more accessible in memory (Fazio and Zanna, 1978) and also because past experience may make low probability events more salient, ensuring that they are accounted for in the formation of intentions (Ajzen and Fishbein, 1980). If employees perceived fairness in previous change processes, they will trust the managers' decisions about change; have less fear and concerns 
about change and consequently be more ready. Based on the literature review, below hypothesis is proposed:

H4: Perceived fairness of previous change will have a positive impact on individual readiness for change.

\section{METHODOLOGY}

\section{Research Goal}

In this survey the main aim is to identify the impact of different variables on individual readiness for change. To test the propositions, a questionnaire was conducted.

\section{Sample and Data Collection}

With convenience sampling method, participants completed the study's instruments on a voluntary basis. The primary data in this study were collected via email. Most of the time the electronic surveys were filled out and sent back to the researcher in a day. Two weeks after the initial emailing, a second follow-up mailing was made to those who had not responded.

The sample of this study included 464 white collar employees [250 female (54\%) and 214 male $(46 \%)$ ]. In terms of their education levels, $20 \%$ of the participants ( $\mathrm{N}=93)$ were high school graduates, $42 \%(\mathrm{~N}=195)$ had a bachelor's degree, 24\% ( $\mathrm{N}=111)$ had a master's degree and $14 \%(\mathrm{~N}=65)$ had a $\mathrm{PhD}$ degree. $60 \%$ of the participants $(\mathrm{N}=278)$ had managerial duties, whereas $40 \%(\mathrm{~N}=186)$ did not have a managerial duty basically working at the clerical level. The participants were working full time in private and public organizations in a wide range of industry sectors including education $(\mathrm{N}=133)$, banking and finance $(\mathrm{N}=40)$, transportation $(\mathrm{N}=35)$, automotive $(\mathrm{N}=27) .68 \%(\mathrm{~N}=316)$ of the participants has a length of employment in their current organization up to 10 years and $23 \%(\mathrm{~N}=107)$ has 10 to 20 years at their current job. $42 \%(\mathrm{~N}=195)$ has a tenure up to 10 years, whereas $38 \%(176)$ of them has 10 to 20 years in work life. The participants were faced with one or more type of organizational changes in their current organizations over the last one year. $72 \%$ of the participants $(\mathrm{N}=334)$ experienced only one type of change, on the other hand, 28\% $(\mathrm{N}=130)$ experienced more than one type of change in their current job in the previous year. Most of the organizations $(43 \%$, $\mathrm{N}=200$ ) were moderately bureaucratic. Data were analyzed through the SPSS statistical packet program and four proposed relations were tested through regression analyses.

\section{Analyses and Results}

This study used 6-point Force Choice Scale illustrated as: 1= Completely Disagree; $2=$ Moderately Disagree; 3= Slightly Disagree; 4= Fairly Agree; 5= Mostly Agree; 6= Completely Agree for self monitoring, fairness of previous change and role ambiguity and $1=$ Never; $2=$ Scarcely; $3=$ Rarely; $4=$ Sometimes; $5=$ Most of the Time; $6=$ Always; for individual readiness for change and job insecurity. To measure self monitoring, 13-item scale of Lennox and Wolfe (1984) is used. It has four dimensions (ability to modify self-presentation; sensitivity to expressive behavior; cross-situation variability and attention to social comparison). Perceived fairness of previous change scale is adopted from Daly and Geyer (1994) which is consist of five questions. Role ambiguity was measured by using 6-item scale developed by Rizzo, House and Lirtzman (1970). To measure job insecurity, 5-item scale of Ashford, Lee and Bobko's (1989) is used. Individual readiness for change was Hanpachern's 14-item scale which was slightly altered by Madsen, Miller and John (2005) to make the items clear for participants.

In order to determine the factor structures of variables, the principal components analysis, method of factor analysis with Varimax rotation was used. Each step was conducted on one- item- a time basis by discarding any item with a factor loading of less than .50, or which loaded to more than one factor with a .10 or less difference, or that singly loaded on a factor. Those factors with Eigenvalues of 1.00 or more were taken into consideration in total variance explained. Those items with more than one factor loading (self monitoring) can be seen on the Table 1. The internal consistencies of the scales were calculated by Cronbach's Alpha and the factors with Alpha values of .70 were considered to have sufficient reliability (Table 2). Table 3, 4, 5 and 6 show the results of regression analyses. 
Journal of Global Strategic Management | V. 6 | N. 1 | 2012-June | isma.info | 102-111 | DOI: 10.20460/JGSM.2012615790

Table 1: Factor Analysis Results

\begin{tabular}{|c|c|c|c|}
\hline SELF MONITORING FACTORS & $\begin{array}{l}\text { Factor } \\
\text { variance \% }\end{array}$ & $\begin{array}{c}\text { Factor } \\
\text { Loading }\end{array}$ & $\begin{array}{l}\text { Cronbach } \\
\text { Alfa }\end{array}$ \\
\hline Factor 1: Sensitivity to expression variability & 44,338 & & ,882 \\
\hline $\begin{array}{l}10 \text { My powers of intuition are quite good when it comes to } \\
\text { understanding others' emotions and motives }\end{array}$ & &, 835 & \\
\hline $\begin{array}{l}9 \text { In conversations, I am sensitive to even the slightest change } \\
\text { in the facial expression of the person I'm conversing with }\end{array}$ & & 823 & \\
\hline $\begin{array}{l}8 \text { I am often able to read people's true emotions correctly } \\
\text { through their eyes }\end{array}$ & &, 819 & \\
\hline $\begin{array}{l}12 \text { I can usually tell when I've said something inappropriate } \\
\text { by reading it in the listener's eyes }\end{array}$ & &, 750 & \\
\hline $\begin{array}{l}13 \text { If someone is lying to me, I usually know it at once from } \\
\text { that person's matter of expression }\end{array}$ & &, 719 & \\
\hline $\begin{array}{l}11 \text { I can usually tell when others consider a joke to be in bad } \\
\text { taste, even though they may laugh convincingly }\end{array}$ & & ,684 & \\
\hline Factor 2: Ability to modify self presentation & 17,859 & & ,827 \\
\hline $\begin{array}{l}3 \text { When I feel that the image I am portraying isn't working, I } \\
\text { can readily change it to something that does }\end{array}$ & & 831 & \\
\hline $\begin{array}{l}\text { I have the ability to control the way I come across to } \\
\text { people, depending on the impression I wish to give them }\end{array}$ & & ,828 & \\
\hline $\begin{array}{l}1 \text { In social situations, I have the ability to later my behavior if } \\
\text { I feel that something else is called for }\end{array}$ & & ,762 & \\
\hline $\begin{array}{l}\text { I have found that I can adjust my behavior to meet the } \\
\text { requirements of any situation I find myself in }\end{array}$ & & 685 & \\
\hline $\begin{array}{l}7 \text { Once I know what the situation calls for, it's easy for me to } \\
\text { regulate my actions accordingly }\end{array}$ & & 606 & \\
\hline
\end{tabular}

KMO: 0,881

62,197

p: ,000 (Bartlett's Test)

Total Variance Explained 
able 2: Cronbach Alpha of Scales

\begin{tabular}{llll}
\hline Concepts & $\begin{array}{l}\text { Number of } \\
\text { Items }\end{array}$ & $\begin{array}{l}\text { Scale } \\
\text { Format }\end{array}$ & $\begin{array}{l}\text { Cronbach } \\
\text { Alpha }\end{array}$ \\
\hline Self Monitoring Factor 1 & 6 & LRFa & 0,882 \\
Self Monitoring Factor 2 & 5 & LRFa & 0,827 \\
Role Ambiguity & 4 & LRFa & 0,893 \\
Job Insecurity & 4 & LRFa & 0,886 \\
Fairness of Previous Change & 3 & LRFa & 0,743 \\
Individual Readiness for Change & 12 & LRFa & 0,879
\end{tabular}

In order to test Hypothesis 1; a regression analysis was conducted to examine the impact of job insecurity on individual readiness for change. Job insecurity has a negative impact on readiness for change $(\beta=-, 161 ; \mathrm{p}=, 001)$ (Table 3$)$.

\section{Table 3. Regression Analysis Results of Job Insecurity on Individual Readiness} for Change

\begin{tabular}{|c|c|c|c|c|c|c|}
\hline Independent Variable & $\begin{array}{c}\text { Adjusted } \\
\mathrm{R}^{2}\end{array}$ & $\mathrm{~F}$ & $\mathrm{P}$ & $\beta$ & $\mathrm{T}$ & $\mathrm{p}$ \\
\hline Job Insecurity &, 024 & 11,137 &, 001 &,- 161 & 3,337 &, 001 \\
\hline
\end{tabular}

In order to test Hypothesis 2; a regression analysis was conducted to examine the impact of self monitoring on individual readiness for change. Self monitoring has a positive impact on readiness for change $(\beta=, 230 ; \mathrm{p}=, 000)$ (Table 4).

\section{Table 4. Regression Analysis Results of Self Monitoring on Individual Readiness} for Change

\begin{tabular}{|c|c|c|c|c|c|c|}
\hline Independent Variable & $\begin{array}{c}\text { Adjusted } \\
\mathrm{R}^{2}\end{array}$ & $\mathrm{~F}$ & $\mathrm{P}$ & $\beta$ & $\mathrm{T}$ & $\mathrm{p}$ \\
\hline Self Monitoring &, 051 & 22,242 &, 000 &, 230 & 4,716 &, 000 \\
\hline
\end{tabular}

In order to test Hypothesis 3; a regression analysis was conducted to examine the impact of role ambiguity on individual readiness for change. Role ambiguity has a negative impact on readiness ( $\beta=$ $-, 191 ; \mathrm{p}=, 000)$ (Table 5).

\section{Table 5. Regression Analysis Results of Role Ambiguity on Individual Readiness for Change}

\begin{tabular}{|c|c|c|c|c|c|c|}
\hline Independent Variable & $\begin{array}{c}\text { Adjusted } \\
\mathrm{R}^{2}\end{array}$ & $\mathrm{~F}$ & $\mathrm{P}$ & $\beta$ & $\mathrm{T}$ & $\mathrm{p}$ \\
\hline Role Ambiguity & 0,34 & 15,969 &, 000 &,- 191 & 3,996 &, 000 \\
\hline
\end{tabular}

In order to test Hypothesis 4; a regression analysis was conducted to examine the impact of perceived fairness of previous change on individual readiness for change. Perceived fairness of previous change has a positive impact on readiness $(\beta=, 810 ; p=, 000)$ (Table 6$)$. 


\section{Table 6. Regression Analysis Results of Perceived Fairness of Previous Change on Individual Readiness for change}

\begin{tabular}{|c|c|c|c|c|c|c|}
\hline Independent Variable & $\begin{array}{c}\text { Adjusted } \\
\mathrm{R}^{2}\end{array}$ & $\mathrm{~F}$ & $\mathrm{P}$ & $\beta$ & $\mathrm{T}$ & $\mathrm{P}$ \\
\hline $\begin{array}{c}\text { Perceived Fairness of } \\
\text { Previous Change }\end{array}$ &, 655 & 811,794 &, 000 &, 810 & 28,492 &, 000 \\
\hline
\end{tabular}

\section{CONCLUSION}

In this study four hypotheses were tested in order to see the impact of job insecurity, role ambiguity, self monitoring and perceived fairness of previous change on individual readiness for change consecutively. All hypotheses were fully supported. The analyses showed that job insecurity and role ambiguity have negative impact on individual readiness for change. Additionally, self monitoring and perceived fairness of previous change have positive impact on individual readiness for change. These findings are consistent with the literature on organizational change. Among all variables, the most striking result was the impact of perceived fairness of previous change. Fairness has always been a cornerstone in management and an essential variable in organizational behavior. This study confirms that perceived fairness of previous change is an important factor that affects individual readiness for change and points out that managers, change agents and consultants should give special attention to this concept in their organizations.

Kotter (1995) suggested that the core issues of organizational changes are not concerned with strategies, structures, cultures or systems, but with how to alter people's behavior. Whether organizational changes could be smoothly promoted or materialized usually depended on the psychological reaction of employees and their process of adaptive behavior. Within this process, the employees' readiness toward organizational changes is especially important (Malone, 2001).

In most studies, individual readiness for change has always been found as a strong antecedent for resistance to change; therefore, it is worthwhile to search this topic especially in our decade, as many organizations invest tremendous resources for change and face many risks for success. From this point of view, this study is both important and timely, because the results of this study intend to provide guidance to managers and change agents by drawing attention to personal and organizational constructs that affect individual readiness for change. As a result, managers can better understand the complexities of employee behavior related to readiness. Knowing employees' readiness for organizational change and their consequences will help change initiators form, adapt and choose from a pool of possible management strategy alternatives in a way to maximize their employees' readiness for change, while minimizing the negative effects of it. Finally, a positive consequence of this research study is the source it can provide for future research hypothesis.

As with all research, there are some potential limitations with respect to this study. The major limitations associated with this research are sampling issues. As surveys are self-reports, they especially reflects certain amount of individual concerns and hold backs about true feelings and thoughts about certain variables such job insecurity and readiness for change. The tenure/ level of job experience of the respondents could possibly affect the responses and in this study, it was not measured. In addition, we must also consider limitations of survey type which was mail survey in this study. Although one of the most common approaches used to study psychological and behavioral variables, it is often criticized as being unreliable. 


\section{REFERENCES}

Ajzen, I. and Fishbein, M. (1980), Understanding Attitudes and Predicting Social Behavior, Englewood Cliffs, NJ: Prentice Hall.

Armenakis, A. A., Harris, S. G. and Mossholder, K. W. (1993), Creating Readiness for Organizational Change, Human Relations, 46 (6), pp. 681- 703.

Ashford, S. J., Lee, C. and Bobko, P. (1989), Content, Causes and Consequences of Job Insecurity: a Theory-Based Measure and Substantive Test, Academy of Management Journal, 32 (4), pp. 803-829.

Backer, T. E. (1995), Assessing and Enhancing Readiness for Change: Implications for Technology Transfer, in T. E. Backer, S. L. David and G. Soucy (Eds.), Reviewing the Behavioral Science Knowledge Base on Technology Transfer, 21-41, Rokville, MD: National Institute on Drug Abuse.

Bagozzi, R. P. (1981), Attitudes, Intentions, and Behaviour: a Test of Some Key Hypotheses, Journal of Personality and Social Psychology, 41 (4), pp. 607-627.

Bedian, A. G. and Armenakis, A. A. (1981), a Path-Analytic Study of the Consequences of Role Conflict and Ambiguity, Academy of Management Journal, 24, pp. 417-424.

Brockner, J., Konovsky, M., Cooper-Schneider, R., Folger, R., Martin, C. and Bies, R. J. (1994), Interactive Effects of Procedural Justice and Outcome Negativity on Victims and Survivors of Job Loss, Academy of Management Journal, 37, pp. 397-409.

Burchell, B. (2002), the Prevalence and Redistribution of Job Insecurity and Work Intensification, in B. Burchell, D. Ladipo and F. Wilkinson (Eds.), Job Insecurity and Work Intensification (pp. 61-76), London: Routledge.

Cunningham, C. E., Woodward, C. A., Shannon, H. R. and MacIntosh, J. (2002), Readiness for Organizational Change: a Longitudinal Study of Workplace, Psychological and Behavioural Correlates, Journal of Occupational and Organizational Psychology, 75, pp. 377-392.

Daly, J. P. and Geyer, P. D. (1994), The Role of Fairness in Implementing Large-Scale Change: Employee Evaluations of Process and Outcome in Seven Facility Relocations, Journal of Organizational Behavior, 15, pp. 623-638.

De Witte, H. (1999), Job Insecurity and Psychological Well-Being: Review of the Literature and Exploration of Some Unresolved Issues, European Journal of Work and Organizational Psychology, 8, pp. 155-179.

Eby, L. T., Adams, D. M. Russell, J. E. A. and Gaby, S. H. (2000), Perceptions of Organizational Readiness for Change: Factors Related to Employees Reactions to the Implementation of Team-Based Selling, Human Relations, 53 (3), pp. 419-442.

Ericsson, K. A. (2004), Deliberate Practice and the Acquisition and Maintenance of Expert Performance in Medicine and Related Domains, Academic Medicine, 79, pp. 70-81.

Evans, E. A. (2001), Executive Commentary, Academy of Management Executive, 15 (4), pp. $94-95$.

Fazio, R. H., and Zanna, M. P. (1978), Attitudinal Qualities Relating to the Strength of the AttitudeBehavior Relationship, Journal of Social Experimental Psychology, 14, pp. 398-408.

Fishbein, M. and I. Ajzen. (1975), Belief, Attitude, Intention, and Behavior: an Introduction to Theory and Research, Reading, MA: Addison Wesley.

Folger, R. and R. Cropanzano. (1998), Organizational Justice and Human Resource Management, Thousand Oaks, CA: Sage.

Folger, R. (1977), Distributive and Procedural Justice: Combined Impact of Voice and Improvement on Experienced Inequity, Journal of Personality and Social Psychology, 35, pp. 108-119.

Forte, M., Hoffman, J. J. Lamont, B. T. and Brockmann, E. N. (2000), Organizational Form and Environment: an Analysis of Between-Form and Within-Form Responses to Environmental Change, Strategic Management Journal, 21, pp. 753-773.

Gangestad, S. W. and Snyder, M. (2000), Self-monitoring: Appraisal and Reappraisal, Psychological Bulletin, 126 (4), pp. 530-555. 
Gordon, S. S., W. H. Stewart, Jr., Sweo, R. and Luker, W A. (2000). Convergence versus Strategic Reorientation: the Antecedents of Fast-Paced Organizational Change, Journal of Management, 26 (5), pp. 911-945.

Greenberg, J. (1987), a Taxonomy of Organizational Justice Theories, Academy of Management Review, 12 (1), pp. 9-22.

Greenhalgh, L. and Rosenblatt, Z.( 1984), Job Insecurity: Towards Conceptual Clarity, Academy of Management Review, 9, 438-448.

Hirsch, P. M. and De Soucey, M. (2006). Organizational Restructuring and its Consequences: Rhetorical and Structural, Annual Review of Sociology, 32, pp. 171-189.

Holt, D. T., Helfrich, C. D., Hall, C. G. and Weiner, B. J. (2009), Are You Ready? How Health Professionals Can Comprehensively Conceptualize Readiness for Change, Journal of General Internal Medicine, 25(Suppl 1), pp.50-55.

Holt, D. T., Armenakis, A. A., Field, H. S. and Harris, S.G. (2007), Readiness for Organizational Change: the Systematic Development of a Scale, The Journal of Applied Behavioral Science, 43, pp. 232-255.

Kahn, R., Wolfe, D., Quinn, R., Snoek, J. and Rosenthal, R. (1964), Organizational Stress: Studies in Role Conflict and Ambiguity, New York, Wiley.

Korsgaard, M. A., Schweiger, D. M. and Sapienza, H. J. (1995), Building Commitment, Attachment, and Trust in Top Management Teams: the Role of Procedural Justice, Academy of Management Journal, 38, pp. 60-84.

Kotter, J. P. (1995), Leading Change: Why Transformation Efforts Fail, Harvard Business Review, 73 (2), pp. 59-67.

Kotter, J. P. and Schlesinger, L. (1979), Choosing Strategies for Change, Harvard Business Review, 57(2), pp. 106-114.

Lennox, R. D. and Wolfe, R. N. (1984), Revision of the Self-Monitoring Scale, Journal of Personality and Social Psychology, 46 (6), pp. 1349-1364.

Madsen, S. R., Miller, D. and John, C. R. (2005), Readiness for Organizational Change: Do Organizational Commitment and Social Relationships in the Workplace Make a Difference? Human Resource Development Quarterly, 16, pp. 213-233.

Noe, R. A., Wilk, S. L., Mullen, E. J. and Wanek, J. E. (1997), Employee Development: Construct Validation Issues, in J. K. Ford, S. W. J.Kozlowski, K. Kraiger, E. Salas and M. S. Teachout (Eds.), Improving Training Effectiveness in Work Organizations, pp. 153-192, Mahwah, NJ: LEA.

Peterson, M. F., Smith, P. B., Akande, A., Ayestaran, S., Bochner, S. and Callan, V. (1995), Role Conflict, Ambiguity and Overload: a 21-Nation Study, Academy of Management Journal. 38, pp. 42945.

Pettigrew, A. (1987), Context and Action in Transforming the Firm, Journal of Management Studies, 24, pp. 649-670.

Petzall, B. J., Parker, G. E. and Stoeberl, P. A. (2000), Another Side to Downsizing: Survivors' Behaviour and Self-Affirmation, Journal of Business and Psychology, 14 (4), pp. 593-602.

Probst, T. M. and Strand, P. (2010), Perceiving and Responding to Job Insecurity: a Workplace Spirituality Perspective, Journal of Management, Spirituality \& Religion, 7 (2), pp. 135-156.

Prochaska, J. O., Norcross, J. C. and DiClemente, C. C. (1994), Changing for Good, New York, NY: William Morrow.

Rafferty, A. E. and Simons, R. H. (2006), an Examination of the Antecedents of Readiness for Fine Tuning and Corporate Transformation Changes, Journal of Business and Psychology, 20 (3), pp. 325350.

Rafferty, A. E., and Simons, R. H. (2001), an Empirical Examination of the Relationship between Change Readiness Perceptions and Types of Change, in D. H. Nagao (Ed.), Academy of Management Proceedings and Membership Directory Washington 2001 - Organization Development \& Change Paper Abstracts (p.6 CD ROM), Georgia USA: Georgia Institute of Technology 
Rizzo, J. R., House, R. J. and Lirtzman, S. I. (1970), Role Conflict and Ambiguity in Complex Organizations, Administrative Science Quarterly, 15, pp. 150-163.

Sokol, M. B. (1997), Consultant's Tool Kit: Personal Lessons of Experience, Consulting Psychology Journal: Practice and Research, 49, pp. 96-107.

Spector, B. A. (1989), from Bogged Down to Fired up: Inspiring Organizational Change, Sloan Management Review, 30, pp. 29-34.

Smith, I. (2005). Achieving Readiness for Organizational Change, Library Management, 26, 6/7, pp. 408.

Snyder, M. and J. Copeland. (1989), Self-monitoring Processes in Organizational Settings, in R. Giacalone and P. Rosenfeld (Eds.), Impression Management in the Organization, 7-19. Hillsdale, NJ: Lawrence Erlbaum.

Snyder, M. (1987), Public Appearances/Public Realities: The Psychology of Self-monitoring, New York: Freeman.

Snyder, D. L. (1979), Self-monitoring Processes, Advances in Experimental Social Psychology, 12, pp. 85-128.

Witten, M. (1989), Whatever Happened To Corporate Loyalty? Canadian Business, 62 (2), pp. 46-53. 